\title{
Effect of Tillage, Crop Residues and Nitrogen Management Practices on Growth Performance and Soil Microbial Parameters in Wheat
}

\author{
Swarna Ronanki ${ }^{1 *}$ and U.K. Behera ${ }^{2}$ \\ ${ }^{1}$ ICAR - India Institute of Millets Research, Rajendranagar, Hyderabad, Telangana, India \\ ${ }^{2}$ ICAR- Indian Agricultural Research Institute, New Delhi, India \\ *Corresponding author
}

\section{A B S T R A C T}

A field experiment was conducted at Indian Agricultural Research Institute, New Delhi during rabi seasons of 2014-15 and 2015-16 to assess the effect of tillage, crop residues and nitrogen management on growth performance and soil microbial parameters in wheat under soybean-wheat cropping system. The experiment was laid out in split plot design with 4 tillage and residue management practices viz., Zero tillage without residue (ZT- R),

\section{Keywords}

Conservation agriculture, Growth, Nitrogen, Soybean, Wheat, Zero tillage

Article Info

Accepted:

10 December 2017

Available Online:

10 January 2018 zero tillage with soybean residue $(\mathrm{ZT}+\mathrm{SR})$, zero tillage with soybean residue and residual effect of preceding wheat residue $(\mathrm{ZT}+\mathrm{SWR})$ and conventional tillage without residue (CT- R) in main plots and 4 nitrogen management practices viz., 100\% recommended dose of nitrogen $(\mathrm{RDN})$ as basal $\left(\mathrm{N}_{1}\right), 125 \% \mathrm{RDN}$ as basal $\left(\mathrm{N}_{2}\right), 100 \%$ basal $+25 \%$ top dressing $\left(\mathrm{N}_{3}\right)$ and $75 \%$ basal $+25 \%$ top dressing $\left(\mathrm{N}_{4}\right)$ in sub plots. The results revealed that the growth parameters of wheat and soil microbial activity were significantly improved with zero tillage \& residue retention. Maximum plant height, LAI and dry matter accumulation (DMA) were observed with $\mathrm{ZT}+\mathrm{SWR}$ and it was on par with ZT+SR and significantly superior to other treatments. Among the no residue treatments, CT - R gave maximum values of growth attributes but was statistically at par with $\mathrm{ZT}-\mathrm{R}$. ZT+SWR recorded 16.5 $\%$ and $25.9 \%$ higher microbial biomass carbon than ZT-R and CT-R respectively. Among the nitrogen management practices, the maximum plant height, LAI, DMA, physiological indices and improved soil microbial parameters were reported with $\mathrm{N}_{2}$ which was found statistically at par with $\mathrm{N} 1$ and significantly superior to rest of the treatments. It is concluded that application of $25 \%$ higher $\mathrm{N}$ over the recommended dose either as basal or as top dressing along with zero tillage plus crop residue could give better growth performance and improved soil microbial properties in wheat.

\section{Introduction}

Conservation agricultural practices has received wide acceptance among the farmers in Indo Gangetic Plains (IGPs) of India as it ensures efficient land utilization, improves soil fertility and provide additional income
(Sharma and Sharma, 2004; Meena et al., 2015). According to FAO (2008), conservation agriculture (CA) is "a concept for resource-saving agricultural crop production that strives to achieve acceptable profits together with high and sustained production levels while concurrently 
conserving the environment. CA consists of different crop cultivation practices such as zero tillage, sowing of crops on permanent beds, strip tillage, plant residue management and adequate crop rotation management. Generally, no till or zero tillage is considered as cornerstone for CA. Compared with conventional practices, zero tillage and residue retention can lead to the improvement of soil physical, chemical, and biological properties and play important roles in maintaining and improving soil quality. Tillage and residue management affect not only soil properties but also soil microbial community. Soil microorganisms play essential roles in agroecosystem, and their changes will influence soil nutrient cycling (He et al., 2007). Notillage with residue application was proved to increase the soil microbial community (Gouaerts et al., 2007).

Research on different aspects of conservation agriculture is being conducted by many scientists in different parts of the world. The area of crops under zero tillage systems has increased significantly in recent years. According to Derpsch and Moriya (1999), the area under zero tillage in 1999 was about 45.5 million hectares. But recent studies on conservation tillage systems show rapid spreading of these systems. At present, CA occupies around 125 million ha in the world, increasing with the rate of 7 million ha annually (FAO, 2011; Friedrich et al., 2012). Today, in the country, the area under conservation tillage has increased to more than 2 million ha. However, there has been little corresponding change in the application rates and management of nutrients especially nitrogen.

In conservation agriculture, application of fertilizer has emerged as an issue due to the fact that under $\mathrm{CA}$, the residue application may hinder the utilization of applied fertilizer. These practices influence the fate of plant nutrients in cropping systems. Both surface residue retention and $\mathrm{ZT}$ potentially induce major changes in $\mathrm{N}$ dynamics and thus $\mathrm{N}$ management in comparison with conventional practice of straw removal and tillage (McConkey et al., 2002; Arora et al., 2010). While ZT may reduce $\mathrm{N}$ mineralization by decreasing decomposition of soil organic matter, particularly in the initial 3-4 years of its adoption, crop residues can influence $\mathrm{N}$ dynamics from immobilization and volatilization (Drinkwater et al., 2000; Singh et al., 2005). Thus proper nitrogen management in conservation agriculture is needed to ensure proper crop growth and development. The present study was therefore designed to determine the effect of different conservation agriculture and nitrogen management practices on growth performance of wheat and soil microbial parameters under soybean-wheat cropping system.

\section{Materials and Methods}

A field experiment was conducted during rabi seasons of 2014-15 and 2015-16 at the research farm of Division of Agronomy, Indian Agricultural Research Institute, New Delhi, situated at $28.4^{\circ} \mathrm{N}$ latitude and $77.1^{\circ} \mathrm{E}$ longitude and at an altitude of 228.6 meters above mean sea level. The climate is semi-arid and temperature is usually warm in most of the period in a year; summer is hot and long and winter is severe and short with average temperatures of $42^{\circ} \mathrm{C}$ and $15^{\circ} \mathrm{C}$, respectively. The soil of the experimental field was a sandy clay loam in texture, neutral in reaction $(\mathrm{pH}$ $7.6)$, low in organic carbon $(0.38 \%)$, low in available $\mathrm{N}(150 \mathrm{~kg} / \mathrm{ha})$, medium in available $\mathrm{P}(11.2 \mathrm{~kg} / \mathrm{ha})$ and available $\mathrm{K}(245 \mathrm{~kg} / \mathrm{ha})$. The total rainfall during the study period was 177.5 and $22 \mathrm{~mm}$ during 2014 and 2015 respectively.

The experiment was laid out in split plot design with three replications in a fixed lay 
out. The main plot treatments consisted of four conservation agricultural practices, viz., Zero Tillage+ No Residue (ZT-R), Zero Tillage + Soybean Residue $(\mathrm{ZT}+\mathrm{SR})$, Zero Tillage + Soybean and Wheat Residue (ZT+SWR) (soybean residue is applied to the wheat crop and wheat residue to the preceding soybean crop) and Conventional Tillage without Residue (CT-R), while the subplot treatments were four nitrogen management practices, viz. $100 \%$ recommended dose of nitrogen (RDN) as basal (N1), $125 \%$ RDN as basal (N2), $100 \%$ basal $+25 \%$ top dressing at crown root initiation (CRI) stage (N3) and $75 \%$ basal + $25 \%$ top dressing at CRI stage (N4).

Under conventional tillage, the plots were ploughed 4-5 times (2 disc harrowing +2 cultivators +1 planking), while in zero-tillage the crop was sown without any tillage operations. Soybean residues @ 3 tonnes/ha were applied to the wheat crop. Wheat (HD 2967) was sown in rows at $20 \mathrm{~cm}$ apart. The $\mathrm{N}, \mathrm{P}$ and $\mathrm{K}$ were given in the form of urea, single super phosphate and muriate of potash, respectively@120:60:40 N, $\mathrm{P}_{2} \mathrm{O}_{5}$. In wheat one blanket spray of glyphosate was made before sowing of the crop only in zero tillage plots followed by application of isoproturon at 30-35 DAS to the whole plots to control the weeds.

The crop growth rate (CGR), relative growth rate (RGR), Net assimilation rate (NAR) and Leaf area duration were calculated using standard formula (Radford, 1967). Soil microbial parameters were recorded at end of the research experiment. Microbial activity in terms of fluorescein diacetate (FDA) hydrolysis in soil was measured by procedure described by Green et al., (2006). The procedure given by Casida et al., (1964) was used for estimation of dehydrogenase activity. Microbial biomass carbon in soil samples was estimated by the method described by Nunan et al., (1998).

\section{Results and Discussion}

\section{Growth attributes}

\section{Plant height}

The plant height of wheat at all stages was markedly influenced due to the conservation agricultural practices and nitrogen management during both the years of experimentation (Table 1). Plant height increased progressively with advancement of crop growth stages. Early phase of growth showed non-significant difference due to conservation agricultural practices during both the year of study. However, in later crop growth stages significantly maximum plant height was observed with the ZT+SWR at par with $\mathrm{ZT}+\mathrm{SR}$ and significantly superior to $\mathrm{CT}-\mathrm{R}$ and $\mathrm{ZT}-\mathrm{R}$. during both the years. The higher growth attributes in zero tilled residue applied plots was due to the improved soil conditions and increased availability of nutrients resulted from the adjustment of abundant microorganisms after straw residue returning to the field (Xu et al., 2010).

Among the various nitrogen management practices, maximum plant height was observed with basal application of $125 \% \mathrm{RDN}$ at all crop growth stages of wheat, which were at par with $100 \%$ basal $+25 \%$ top dressing and significantly superior to other two treatments. The shortest plant height was observed with $75 \%$ basal $+25 \%$ top dressing and it was at par with basal application of $100 \%$ RDN during both the years of study.

The increase in plant height with increased nitrogen application might be due to enhanced vegetative growth with more $\mathrm{N}$ supply to plant (Olsen et al., 2002). There was no-significant interactive effect of conservation agricultural practices and nitrogen management on plant height during both the years of experimentation. 


\section{Dry matter accumulation}

The dry matter accumulation was significantly affected by the conservation agricultural practices and nitrogen management (Table 2). As is evident from the data, the dry matter accumulation was slow during initial stages, then increased steadily with the advancement of age of crop and attained maximum value at maturity. The highest dry matter was accumulated with ZT+SWR and it was at par with $\mathrm{ZT}+\mathrm{SR}$ and significantly superior to rest of the treatments during both the years of study. In ZT+SWR the DMA was improved by $14.1,10.5,11.4$ and $12.1 \%$ at $60,90,120$ DAS and at maturity compared to ZT-R during 2014-15 and 13.3, 17.6, 13.7 and 12\% during 2015-16. The highest dry matter accumulation in zero tillage with residue retention might be due to moderated soil temperature, favorable soil moisture and improved soil biota by constant supply of nutrients through mineralization of residues (Kumar et al., 2017).

Among the nitrogen management practices basal application of $125 \% \mathrm{RDN}$ recorded highest dry matter accumulation which were at par with $100 \%$ basal $+25 \%$ top dressing and was significantly superior over basal application of $100 \%$ RDN and $75 \%$ basal + $25 \%$ top dressing. Nitrogen is considered to be vitally important plant nutrient. It is necessary for chlorophyll synthesis and as a part of the chlorophyll molecule, which is the primary absorber of light energy needed for photosynthesis. Thus increasing the amount of $\mathrm{N}$ increased the chlorophyll content to the maximum and the dry matter accumulation (Rahman et al., 2014).

\section{Leaf area index}

The data pertaining to LAI was influenced significantly under various conservation agricultural practices and nitrogen management treatments at 30, 60, 90 and 120 DAS (Table 3). Initially at 30 days crop, the LAI was the lowest, increased with advancing age of plant and highest values were obtained at later stage of crop during both the years.

The highest LAI values at different growth stages were obtained under $\mathrm{ZT}+\mathrm{SWR}$ and it was on par with $\mathrm{ZT}+\mathrm{SR}$ and the lowest were under ZT- R which in turn on par with CT- R during 2014-15 and 2015-16. This was possibly due to enhanced soil health and micro-environment by implementation of zero tillage and residue retention practices (Kumar et al., 2017).

Among the nitrogen management treatments, basal application of $125 \%$ RDN recorded highest LAI which were onpar with 100\% basal $+25 \%$ top dressing and was significantly superior over basal application of $100 \%$ RDN and $75 \%$ basal $+25 \%$ top dressing. This might be due to favorable synthesis of growth favouring constituents in plant system due to better supply of nitrogen, which led to the increased number of leaves per unit area resulting in enlargement in leaf area (Alam, 2013).

\section{Physiological indices}

\section{Mean crop growth rate (CGR)}

The mean crop growth rate of wheat was markedly influenced by conservation agricultural practices and nitrogen management (Table 4). In general, the CGR values were lowest between 0 to 30 days, increased gradually and attained highest values between 60 to 90 days and further decreased near maturity. Mean CGR was highest under $\mathrm{ZT}+\mathrm{SWR}$ but at later stages it was found to be non-significant during both the year of study except at 60-90 DAS during second year in which mean CGR with $\mathrm{ZT}+\mathrm{SWR}$ and $\mathrm{ZT}+\mathrm{SR}$ were found at par. 
Table.1 Plant height $(\mathrm{cm})$ of wheat as influenced by conservation agricultural practices and nitrogen management

\begin{tabular}{|c|c|c|c|c|c|c|c|c|c|c|}
\hline \multirow[t]{2}{*}{ Treatment } & \multicolumn{2}{|c|}{30 DAS } & \multicolumn{2}{|c|}{60 DAS } & \multicolumn{2}{|c|}{90 DAS } & \multicolumn{2}{|c|}{120 DAS } & \multicolumn{2}{|c|}{ Maturity } \\
\hline & $2014-15$ & $2015-16$ & $2014-15$ & 2015-16 & 2014-15 & 2015-16 & $2014-15$ & $2015-16$ & 2014-15 & $2015-16$ \\
\hline \multicolumn{11}{|c|}{ Conservation agricultural practices (Tillage \& Residue management) } \\
\hline $\mathbf{Z T}-\mathbf{R}$ & 26.2 & 27.3 & 41.25 & 43.47 & 68.02 & 72.79 & 86.24 & 93.40 & 101.33 & 103.87 \\
\hline $\mathrm{ZT}+\mathrm{SR}$ & 26.9 & 27.7 & 47.23 & 48.26 & 76.85 & 78.06 & 98.73 & 93.72 & 101.02 & 104.53 \\
\hline$\overline{Z T+S W R}$ & 28.9 & 28.9 & 48.39 & 48.49 & 77.66 & 78.45 & 99.33 & 94.74 & 101.45 & 105.31 \\
\hline $\mathrm{CT}-\mathrm{R}$ & 28.9 & 28.3 & 41.42 & 43.52 & 69.76 & 73.18 & 87.15 & 94.29 & 100.80 & 104.81 \\
\hline SEm \pm & 0.73 & 0.44 & 1.14 & 1.05 & 1.88 & 1.25 & 2.73 & 1.90 & 4.24 & 3.64 \\
\hline LSD $(P=0.05)$ & NS & NS & 3.94 & 3.62 & 6.50 & 4.31 & 9.43 & NS & NS & NS \\
\hline \multicolumn{11}{|l|}{ Nitrogen management } \\
\hline N1 (100\% Basal) & 27.6 & 27.9 & 42.46 & 44.17 & 68.78 & 72.23 & 86.50 & 88.13 & 91.86 & 94.40 \\
\hline N2 (125\% Basal) & 28.7 & 29.4 & 47.43 & 48.63 & 79.19 & 80.78 & 100.80 & 101.28 & 111.05 & 116.14 \\
\hline $\begin{array}{l}\mathrm{N} 3(100 \% \text { Basal + } 25 \% \text { top } \\
\text { dressing) }\end{array}$ & 27.4 & 27.9 & 45.66 & 46.62 & 76.70 & 78.39 & 98.57 & 99.80 & 109.81 & 113.79 \\
\hline $\begin{array}{l}\mathrm{N} 4(75 \% \text { Basal + } 25 \% \text { top } \\
\text { dressing) }\end{array}$ & 27.3 & 26.9 & 42.75 & 44.32 & 67.62 & 71.07 & 85.57 & 86.93 & 91.89 & 94.19 \\
\hline SEm & 0.33 & 0.43 & 1.07 & 0.85 & 2.13 & 1.43 & 2.66 & 2.58 & 3.59 & 3.64 \\
\hline LSD $(P=0.05)$ & 0.97 & 1.24 & 3.11 & 2.49 & 6.22 & 4.17 & 7.75 & 7.52 & 10.48 & 10.61 \\
\hline
\end{tabular}

ZT-R: Zero till without residues; ZT+SR: Zero with soybean residues in wheat crop; ZT+SWR: Zero till with soybean residue in wheat and wheat residue in preceeding soybean crop; CT-R: Conventional till without residues 
Table.2 Dry matter accumulation $\left(\mathrm{g} / \mathrm{m}^{2}\right)$ of wheat as influenced by conservation agricultural practices and nitrogen management

\begin{tabular}{|c|c|c|c|c|c|c|c|c|c|c|}
\hline \multirow[t]{2}{*}{ Treatment } & \multicolumn{2}{|c|}{30 DAS } & \multicolumn{2}{|c|}{60 DAS } & \multicolumn{2}{|c|}{90 DAS } & \multicolumn{2}{|c|}{120 DAS } & \multicolumn{2}{|c|}{ Maturity } \\
\hline & 2014-15 & $2015-16$ & 2014-15 & $2015-16$ & 2014-15 & $2015-16$ & 2014-15 & $2015-16$ & 2014-15 & $2015-16$ \\
\hline \multicolumn{11}{|c|}{ Conservation agricultural practices } \\
\hline$\overline{\mathbf{Z T}-\mathbf{R}}$ & 36.83 & 33.02 & 148.0 & 136.1 & 608.9 & 551.9 & 1091.4 & 1019.8 & 1449.4 & 1421.1 \\
\hline$\overline{\mathrm{ZT}+\mathrm{SR}}$ & 37.37 & 34.94 & 171.9 & 151.2 & 661.9 & 642.5 & 1187.9 & 1140.7 & 1598.2 & 1571.3 \\
\hline$\overline{\mathrm{ZT}+\mathrm{SWR}}$ & 38.83 & 35.28 & 172.3 & 156.9 & 680.1 & 669.6 & 1231.2 & 1181.4 & 1649.6 & 1614.6 \\
\hline $\mathbf{C T}-\mathbf{R}$ & 36.74 & 33.56 & 156.5 & 142.7 & 614.3 & 625.8 & 1100.3 & 1077.5 & 1570.8 & 1534.9 \\
\hline SEm \pm & 0.53 & 0.93 & 3.76 & 3.69 & 15.12 & 10.92 & 29.40 & 28.58 & 32.06 & 27.97 \\
\hline $\operatorname{LSD}(P=0.05)$ & NS & NS & 13.03 & 12.77 & 52.32 & 37.80 & 101.74 & 98.92 & 110.9 & 96.80 \\
\hline \multicolumn{11}{|l|}{ Nitrogen management } \\
\hline N1 (100\% Basal) & 35.42 & 33.56 & 153.1 & 138.0 & 603.6 & 592.6 & 1095.3 & 1055.8 & 1510.6 & 1472.3 \\
\hline N2 (125\% Basal) & 39.80 & 35.49 & 171.7 & 156.1 & 664.9 & 656.9 & 1211.5 & 1152.0 & 1628.5 & 1602.5 \\
\hline $\begin{array}{l}\text { N3 (100\% Basal + } 25 \% \\
\text { top dressing) }\end{array}$ & 38.84 & 35.03 & 170.2 & 156.4 & 673.1 & 656.6 & 1210.7 & 1145.2 & 1614.7 & 1597.7 \\
\hline $\begin{array}{l}\text { N4 }(75 \% \text { Basal + } 25 \% \text { top } \\
\text { dressing) }\end{array}$ & 35.70 & 32.71 & 153.8 & 136.4 & 623.7 & 583.7 & 1093.2 & 1066.3 & 1514.3 & 1469.5 \\
\hline SEmt & 0.67 & 0.67 & 3.58 & 3.92 & 17.51 & 21.91 & 36.68 & 28.62 & 35.05 & 41.81 \\
\hline $\operatorname{LSD}(P=0.05)$ & 1.97 & 1.96 & 10.45 & 11.43 & 51.11 & 63.94 & 107.07 & 83.53 & 102.30 & 122.04 \\
\hline
\end{tabular}

ZT-R: Zero till without residues; ZT+SR: Zero with soybean residues in wheat crop; ZT+SWR: Zero till with soybean residue in wheat and wheat residue in preceeding soybean crop; CT-R: Conventional till without residues 
Table.3 Leaf area index of wheat as influenced by conservation agricultural practices and nitrogen management

\begin{tabular}{|c|c|c|c|c|c|c|c|c|}
\hline \multirow[t]{2}{*}{ Treatment } & \multicolumn{2}{|c|}{30 DAS } & \multicolumn{2}{|c|}{60 DAS } & \multicolumn{2}{|c|}{90 DAS } & \multicolumn{2}{|c|}{120 DAS } \\
\hline & $\begin{array}{c}2014- \\
15\end{array}$ & $\begin{array}{c}2015- \\
16\end{array}$ & $\begin{array}{c}2014- \\
15\end{array}$ & $\begin{array}{c}2015- \\
16\end{array}$ & $\begin{array}{c}2014- \\
15\end{array}$ & $\begin{array}{c}2015- \\
16\end{array}$ & $\begin{array}{c}2014- \\
15\end{array}$ & $\begin{array}{c}2015- \\
16\end{array}$ \\
\hline \multicolumn{9}{|l|}{ Conservation agricultural practices } \\
\hline $\mathbf{Z T}-\mathbf{R}$ & 0.38 & 0.38 & 2.13 & 1.77 & 3.86 & 3.59 & 2.16 & 1.93 \\
\hline $\mathrm{ZT}+\mathrm{SR}$ & 0.41 & 0.43 & 2.33 & 2.08 & 4.10 & 3.93 & 2.36 & 2.12 \\
\hline$\overline{\mathrm{ZT}+\mathrm{SWR}}$ & 0.44 & 0.46 & 2.44 & 2.31 & 4.59 & 4.15 & 2.61 & 2.38 \\
\hline $\mathbf{C T}-\mathbf{R}$ & 0.40 & 0.40 & 2.29 & 2.07 & 3.95 & 3.81 & 2.19 & 2.04 \\
\hline SEm \pm & 0.01 & 0.00 & 0.04 & 0.06 & 0.07 & 0.04 & 0.02 & 0.04 \\
\hline LSD $(P=0.05)$ & 0.02 & 0.02 & 0.13 & 0.22 & 0.23 & 0.14 & 0.07 & 0.15 \\
\hline \multicolumn{9}{|l|}{ Nitrogen management } \\
\hline N1 (100\% Basal) & 0.39 & 0.40 & 2.13 & 1.96 & 4.01 & 3.72 & 2.25 & 1.98 \\
\hline N2 (125\% Basal) & 0.44 & 0.45 & 2.45 & 2.18 & 4.31 & 4.06 & 2.45 & 2.25 \\
\hline N3 (100\% Basal + $25 \%$ top dressing) & 0.42 & 0.43 & 2.41 & 2.16 & 4.24 & 4.00 & 2.43 & 2.19 \\
\hline N4 (75\% Basal + $25 \%$ top dressing) & 0.37 & 0.38 & 2.20 & 1.94 & 3.94 & 3.69 & 2.18 & 2.05 \\
\hline SEm \pm & 0.01 & 0.01 & 0.05 & 0.05 & 0.10 & 0.09 & 0.04 & 0.04 \\
\hline LSD $(P=0.05)$ & 0.02 & 0.02 & 0.15 & 0.13 & 0.29 & 0.27 & 0.13 & 0.12 \\
\hline
\end{tabular}

ZT-R: Zero till without residues; ZT+SR: Zero with soybean residues in wheat crop; ZT+SWR: Zero till with soybean residue in wheat and wheat residue in preceeding soybean crop; CT-R: Conventional till without residues 
Table.4 Crop growth rate (CGR, g/g/day) of wheat as influenced by conservation agricultural practices and nitrogen management

\begin{tabular}{|c|c|c|c|c|c|c|c|c|}
\hline \multirow[t]{2}{*}{ Treatment } & \multicolumn{2}{|c|}{ 0-30 DAS } & \multicolumn{2}{|c|}{ 30-60 DAS } & \multicolumn{2}{|c|}{ 60-90 DAS } & \multicolumn{2}{|c|}{ 90-120 DAS } \\
\hline & 2014-15 & $2015-16$ & 2014-15 & $2015-16$ & 2014-15 & $2015-16$ & 2014-15 & $2015-16$ \\
\hline \multicolumn{9}{|l|}{$\begin{array}{l}\text { Conservation agricultural } \\
\text { practices }\end{array}$} \\
\hline $\mathbf{Z T}-\mathbf{R}$ & 1.228 & 1.101 & 3.706 & 3.434 & 15.362 & 13.862 & 16.084 & 15.596 \\
\hline $\mathrm{ZT}+\mathrm{SR}$ & 1.246 & 1.165 & 4.486 & 3.876 & 16.333 & 16.376 & 17.534 & 16.608 \\
\hline$\overline{Z T+S W R}$ & 1.294 & 1.176 & 4.450 & 4.056 & 16.927 & 17.087 & 18.367 & 17.059 \\
\hline $\mathbf{C T}-\mathbf{R}$ & 1.225 & 1.119 & 3.993 & 3.639 & 15.259 & 16.101 & 16.200 & 15.058 \\
\hline SEm \pm & 0.018 & 0.031 & 0.116 & 0.128 & 0.551 & 0.410 & 1.040 & 1.076 \\
\hline LSD $(P=0.05)$ & NS & NS & 0.400 & NS & NS & 1.418 & NS & NS \\
\hline \multicolumn{9}{|l|}{ Nitrogen management } \\
\hline N1 (100\% Basal) & 1.181 & 1.119 & 3.923 & 3.482 & 15.016 & 15.152 & 16.391 & 15.440 \\
\hline N2 (125\% Basal) & 1.327 & 1.183 & 4.395 & 4.021 & 16.440 & 16.693 & 18.223 & 16.504 \\
\hline $\begin{array}{l}\text { N3 (100\% Basal + 25\% top } \\
\text { dressing) }\end{array}$ & 1.295 & 1.168 & 4.380 & 4.045 & 16.760 & 16.673 & 17.922 & 16.289 \\
\hline $\begin{array}{l}\text { N4 }(75 \% \text { Basal + } 25 \% \text { top } \\
\text { dressing) }\end{array}$ & 1.190 & 1.090 & 3.936 & 3.457 & 15.665 & 14.908 & 15.650 & 16.088 \\
\hline SEm \pm & 0.022 & 0.022 & 0.128 & 0.136 & 0.542 & 0.735 & 1.297 & 1.066 \\
\hline LSD $(P=0.05)$ & 0.066 & 0.065 & 0.374 & 0.398 & NS & NS & NS & NS \\
\hline
\end{tabular}

ZT-R: Zero till without residues; ZT+SR: Zero with soybean residues in wheat crop; ZT+SWR: Zero till with soybean residue in wheat and wheat residue in preceeding soybean crop; CT-R: Conventional till without residues 
Table.5 Relative growth rate (RGR, mg/g/day) of wheat as influenced by conservation agricultural practices and nitrogen management

\begin{tabular}{|c|c|c|c|c|c|c|}
\hline \multirow[t]{2}{*}{ Treatment } & \multicolumn{6}{|c|}{ RGR } \\
\hline & 2014-15 & 2015-16 & 2014-15 & $2015-16$ & 2014-15 & $2015-16$ \\
\hline \multicolumn{7}{|l|}{ Conservation agricultural practices } \\
\hline$\overline{\mathbf{Z T}-\mathbf{R}}$ & 46.26 & 47.24 & 47.05 & 46.74 & 19.52 & 20.47 \\
\hline$\overline{\mathrm{ZT}+\mathrm{SWR}}$ & 49.65 & 49.59 & 45.81 & 48.41 & 19.69 & 18.88 \\
\hline $\mathrm{CT}-\mathrm{R}$ & 48.34 & 48.15 & 45.44 & 49.26 & 19.44 & 18.18 \\
\hline SEm \pm & 0.70 & 1.23 & 1.22 & 1.20 & 1.10 & 1.09 \\
\hline LSD $(P=0.05)$ & 2.41 & NS & NS & NS & NS & NS \\
\hline N2 (125\% Basal) & 48.66 & 49.29 & 45.10 & 47.83 & 20.04 & 18.76 \\
\hline N3 $(100 \%$ Basal $+25 \%$ top dressing) & 49.22 & 49.67 & 45.85 & 47.88 & 19.46 & 18.68 \\
\hline N4 (75\% Basal + 25\% top dressing) & 48.55 & 47.62 & 46.71 & 48.29 & 18.65 & 20.22 \\
\hline SEm \pm & 1.11 & 1.21 & 0.88 & 1.42 & 1.38 & 1.26 \\
\hline LSD $(P=0.05)$ & NS & NS & NS & NS & NS & NS \\
\hline
\end{tabular}

ZT-R: Zero till without residues; ZT+SR: Zero with soybean residues in wheat crop; ZT+SWR: Zero till with soybean residue in wheat and wheat residue in preceeding soybean crop; CT-R: Conventional till without residues 
Table.6 Net assimilation rate (NAR, $\mathrm{mg} / \mathrm{m}^{2}$ leaf area/day) of wheat as influenced by conservation agricultural practices and nitrogen management

\begin{tabular}{|c|c|c|c|c|c|c|}
\hline \multirow[t]{3}{*}{ Treatment } & \multicolumn{6}{|c|}{ NAR } \\
\hline & \multicolumn{2}{|c|}{ 30-60 DAS } & \multicolumn{2}{|c|}{ 60-90 DAS } & \multicolumn{2}{|c|}{ 90-120 DAS } \\
\hline & 2014-15 & $2015-16$ & 2014-15 & $2015-16$ & 2014-15 & $2015-16$ \\
\hline \multicolumn{7}{|l|}{ Conservation agricultural practices } \\
\hline $\mathbf{Z T}-\mathbf{R}$ & 3.644 & 3.824 & 5.270 & 5.420 & 5.544 & 5.864 \\
\hline $\mathbf{Z T}+\mathbf{S R}$ & 4.083 & 3.707 & 5.241 & 5.636 & 5.587 & 5.707 \\
\hline$\overline{\mathrm{ZT}+\mathrm{SWR}}$ & 3.847 & 3.537 & 4.997 & 5.447 & 5.248 & 5.391 \\
\hline $\mathbf{C T}-\mathbf{R}$ & 3.697 & 3.618 & 5.025 & 5.656 & 5.442 & 5.318 \\
\hline SEm \pm & 0.089 & 0.180 & 0.195 & 0.157 & 0.385 & 0.354 \\
\hline $\operatorname{LSD}(P=0.05)$ & 0.307 & NS & NS & NS & NS & NS \\
\hline \multicolumn{7}{|l|}{ Nitrogen management } \\
\hline N1 (100\% Basal) & 3.813 & 3.578 & 5.051 & 5.521 & 5.400 & 5.603 \\
\hline N2 (125\% Basal) & 3.767 & 3.686 & 5.006 & 5.535 & 5.555 & 5.420 \\
\hline N3 (100\% Basal + $25 \%$ top dressing) & 3.864 & 3.792 & 5.203 & 5.599 & 5.540 & 5.454 \\
\hline N4 (75\% Basal + $25 \%$ top dressing) & 3.827 & 3.630 & 5.273 & 5.503 & 5.325 & 5.803 \\
\hline SEm \pm & 0.139 & 0.164 & 0.185 & 0.261 & 0.454 & 0.393 \\
\hline $\operatorname{LSD}(P=0.05)$ & NS & NS & NS & NS & NS & NS \\
\hline
\end{tabular}

ZT-R: Zero till without residues; ZT+SR: Zero with soybean residues in wheat crop; ZT+SWR: Zero till with soybean residue in wheat and wheat residue in preceeding soybean crop; CT-R: Conventional till without residues 
Table.7 Effect of conservation agricultural practices and nitrogen management on biological properties of soil in soybean-wheat cropping system

\begin{tabular}{|c|c|c|c|c|}
\hline Treatment & $\begin{array}{l}\text { FDA } \\
\text { (ug fluorescein } \\
\left.\mathrm{g}^{-1} \text { soil } \mathrm{hr}^{-1}\right)\end{array}$ & $\begin{array}{l}\text { Alkaline } \\
\text { phosphatise } \\
\left(\mathbf{u g ~ h r} \mathbf{g}^{-1} \text { soil) }\right.\end{array}$ & $\begin{array}{l}\text { Dehydrogenase } \\
\text { (TPF hr } \mathrm{hr}^{-1} \mathrm{~g}^{-1} \\
\text { soil) }\end{array}$ & $\begin{array}{l}\text { Microbial biomass carbon } \\
\left(\mathrm{ug} \mathrm{g}^{-1} \text { soil) }\right.\end{array}$ \\
\hline \multicolumn{5}{|c|}{ Conservation agricultural practices } \\
\hline $\mathbf{Z T}-\mathbf{R}$ & 3.60 & 8.83 & 6.50 & 131.86 \\
\hline $\mathbf{Z T}+\mathbf{S R}$ & 4.34 & 10.91 & 7.21 & 143.81 \\
\hline $\mathbf{Z T}+\mathbf{S W R}$ & 4.71 & 11.96 & 7.97 & 153.55 \\
\hline $\mathbf{C T}-\mathbf{R}$ & 3.30 & 7.99 & 5.74 & 121.91 \\
\hline SEm \pm & 0.14 & 0.39 & 0.14 & 5.27 \\
\hline LSD $(P=0.05)$ & 0.48 & 1.36 & 0.49 & 18.25 \\
\hline \multicolumn{5}{|l|}{ Nitrogen management } \\
\hline N1 (100\% Basal) & 3.78 & 9.32 & 6.76 & 129.15 \\
\hline N2 (125\% Basal) & 4.16 & 10.41 & 7.27 & 154.41 \\
\hline $\begin{array}{l}\text { N3 (100\% Basal }+25 \% \text { top } \\
\text { dressing) }\end{array}$ & 4.13 & 10.33 & 7.05 & 139.07 \\
\hline $\begin{array}{l}\text { N4 }(75 \% \text { Basal }+25 \% \text { top } \\
\text { dressing) }\end{array}$ & 3.89 & 9.64 & 6.34 & 128.49 \\
\hline SEm & 0.08 & 0.24 & 0.16 & 4.82 \\
\hline LSD $(P=0.05)$ & 0.25 & 0.70 & 0.48 & 14.08 \\
\hline
\end{tabular}

ZT-R: Zero till without residues; ZT+SR: Zero with soybean residues in wheat crop; ZT+SWR: Zero till with soybean residue in wheat and wheat residue in preceeding soybean crop; CT-R: Conventional till without residues 
Residue retention in zero tillage plots increase infiltration rate, soil organic matter which facilitate easy nutrient availability to the plants, resulted better plant growth and development (Jat et al., 2017). Nitrogen management practices, significantly influenced the mean CGR only in the initial stages later it was found non-significant during both the years of study. Highest mean CGR at $0-30$ and $30-60$ was found with basal application of $125 \%$ RDN which were onpar with $100 \%$ basal $+25 \%$ top dressing and was significantly superior over basal application of $100 \%$ RDN and $75 \%$ basal $+25 \%$ top dressing. This was due to the role of nitrogen in production and translocation of cytokinin from the root to the shoots. Thus increased levels of nitrogen application increases cell division rate and crop growth (Timothy and Joe, 2003).

\section{Relative growth rate (RGR) and net assimilation rate (NAR)}

In general, the mean RGR and NAR were higher during 30 to 60 days crop and later decreased between 60 to 90 and 90 to 120 days duration. Data related to RGR and NAR showed that under different conservation agricultural practices and nitrogen management it was not significantly affected (Table 5 and 6). However numerically higher values of mean RGR and mean NAR were observed with $\mathrm{ZT}+\mathrm{SWR}$ followed by $\mathrm{ZT}+\mathrm{SR}, \mathrm{CT}+\mathrm{NR}$ and $\mathrm{ZT}+\mathrm{NR}$.

Residue retention in zero tilled plots resulted in higher organic carbon, improved soil porosity, enhanced microbial population and infiltration rate which provided more favourable conditions for the crop growth and development (Jat et al., 2014). Among the nitrogen management practices, basal application of $125 \%$ RDN gave numerically higher values of mean CGR and mean RGR followed by $100 \%$ basal $+25 \%$ top dressing, basal application of $100 \% \mathrm{RDN}$ and $75 \%$ basal $+25 \%$ top dressing. Since nitrogen increases photosynthetic tissues, higher nitrogen fertilizer has higher RGR (Azarpour et al., 2014).

\section{Soil microbial parameters}

The different conservation agricultural practices differed significantly with respect to soil microbial parameters (dehydrogenase, alkaline phosphatase, FDA and MBC) estimated after harvest of second season wheat crop (Table 7). ZT+SWR resulted in significantly highest activity of dehydrogenase, alkaline phosphatase, FDA and MBC in soil after harvest of wheat crop of the soybean-wheat cropping system. Critical examination of data further revealed that application of residues significantly increased the microbial activities in soil after harvest of crops as compared to no residue treatments.

The balanced amount of nutrients supplied, maintained and slightly increased the nutrients availability and organic carbon content in soil after the decomposition of residues served as a substrate for better activity of microbes that ultimately reflected in higher enzymatic activity in soil. The balanced nutrient supply improves the root biomass and rhizosphere leading to higher microbial and enzymatic activities in soil. Dong et al., (2009) reported that the mean annual MBC was highest under no-tillage with residue, while lowest in conventional tillage. The no tillage system having crop residue showed increase of $103 \%, 54 \%$ and $36 \%$ for $\mathrm{MBC}, \mathrm{N}$ and $\mathrm{P}$, respectively at the 0 to $5 \mathrm{~cm}$ depth than CT (Balato et al., 2003).

And among the nitrogen management practices, application of $125 \%$ RDN treatments either as basal or top dressing resulted in significantly higher activity of dehydrogenase, alkaline phosphatase, FDA and MBC. This shows that higher rate of $\mathrm{N}$ fertilization enhanced the activities of soil enzymes without any detrimental effect on the enzyme dynamics of the soil. This is because nitrogen not only provide necessary mineral elements for plant growth, but also act as important indicator for soil natural fertility as there is a close relationship between soil nutrients and soil enzyme activity (Malvi, 2011). 
Due to continuous intensive tillage practices in conventional agriculture system and indiscriminate and imbalance use of fertilizers, productivity of wheat has been plateau or shown a decline trend in IGP which needs to be sustained or enhanced by using conservation agricultural practices on long term basis. The study revealed that significantly higher growth performance of wheat and increased microbial activity in soil can be achieved under zero tillage with residue retention plots as compared to conventional tillage without residues. Applications of $25 \%$ higher recommended dose of nitrogen either as basal or top dressing significantly improved the growth performance of wheat. Thus zero tillage with soybean and wheat residues coupled with application of $25 \%$ higher recommended dose of nitrogen would improve the soil biological health and better growth performance of wheat in IGP of India.

\section{References}

Alam, M.S. 2013. Growth and yield potentials of wheat as affected by management practices. African Journal of Agricultural Research, 8(47): 6068-6072.

Arora, V.K., Sidhu, A.S., Sandhu, K.S., Thind, S.S. 2010. Effects of tillage intensity, planting time and nitrogen rate on wheat yield following rice. Experimental Agriculture 46: 267-275.

Azarpour, E., Amiri, E., Kashani, A., Khodabande, N. and Moradi, M. 2012. Evaluation of some growth indices on vegetative and reproductive stage of rice cultivars under nitrogen fertilizer management. Journal of Biology Science, 5(4): $1-10$

Balato E L, Colozzi-Filho A, Andrade D S and Dick R P. 2003. Microbial biomass in soils under different tillage and crop rotation systems. Biology and Fertility of Soils 38: 15-20.

Casida L E J, Klein D A and Santaro T. 1964. Soil dehydrogenase activity. Soil Science 98: 371-376

Derpsch, R. and Moriya, K. 1999. Implications of soil preparation as compared to no- tillage on the sustainability of crop production: experiences from South America. In Management of tropical agro-ecosystems and the beneficial soil biota (ed. M. V. Reddy), pp. 49-65. Enfield, NH: Science Publishers.

Dong W, Hu C, Chen S and Zhang Y. 2009. Tillage and residue management effects on soil carbon and $\mathrm{CO}_{2}$ emission in wheat - corn double-cropping system. Nutrient Cycling in Agroecosystems 83: 27 - 37.

Drinkwater, L.E., Janke, R.R. and RossoniLongnecker, L. 2000. Effects of tillage intensity on nitrogen dynamics and productivity in legume-based grain systems. Plant and Soil 227: 99-113.

FAO, 2008. What is Conservation Agriculture. in: Conservation Agriculture website of FAO, http://www.fao.org/ag/ca/1a.html

FAO. 2011. CA Adoption Worldwide: FAOCA available online http://www.fao.org/ ag/ca/6c.html.

Friedrich, T., Derpsch, R. and Kassam, A. 2012. Overview of the global spread of conservation agriculture, Field Actions Science Reports, Special Issue 6.

Gouaerts, B., Mezzalama, M., Unno, Y., Sayre, K. D., Luna-Guido, M., Vanherck, K., Dendoouen L. and Deckers J. 2007. Influence of tillage, residue management, and crop rotation on soil microbial biomass and catabolic diversity. Applied Soil Ecology, 37: 18-30.

Green, V. S., Stott, D. E and Diack, M. 2006. Assay for fluorescein diacetate hydrolytic activity: optimization for soil samples. Soil Biology and Biochemistry 38(4): 693-701.

He, J.Z., Shen, J. P., Zhang, L. M., Zhu, Y. G., Zheng Y. M., Xu, M.G., Di, H. 2007. Quantitative analyses of the abundance and composition of ammonia-oxidizing bacteria and ammonia-oxidizing archaea of a Chinese upland red soil under longterm fertilization practices. Environmental Microbiology, 9: 23642374.

Jat, H.S., Datta, A., Sharma, P.C., Kumar, V., Yadav, A.K., Choudhary, M., Choudhary, 
V., Gathala, M.K., Sharma, D.K., Jat, M.L. and Yaduvanshi, N. P. S. 2017. Assessing soil properties and nutrient availability under conservation agriculture practices in a reclaimed sodic soil in cereal-based systems of NorthWest India. Archives of Agronomy and Soil Science: 1-15.

Jat, R.K., Sapkota, T.B., Singh, R.G., Jat, M.L., Kumar, M. and Gupta, R.K., 2014. Seven years of conservation agriculture in a rice-wheat rotation of Eastern Gangetic Plains of South Asia: yield trends and economic profitability. Field Crops Research, 164: 199-210.

Kumar, N., Kamboj, B.R., Thakral, S.K. and Singh, M., 2017. Growth Parameters and Productivity of Wheat as Influenced by Crop Establishment Methods and Different Seed Rate. International Journal of Pure and Applied Bioscience, 5(4): 2134-2140.

Malvi, U.R. 2011. Interaction of micronutrients with major nutrients with special reference to potassium. Karnataka Journal of Agricultural Sciences, 24(1): 106-109

McConkey, B.G., Curtin, D., Campbell, C.A., Brandt, S.A. and Selles, F. 2002. Crop and soil nitrogen status of tilled and notillage systems in semiarid regions of Saskatchewan. Canadian Journal of Soil Science 82: 489-498.

Meena, J.R., Behera, U.K., Chakraborty, D. and Sharma, A.R., 2015. Tillage and residue management effect on soil properties, crop performance and energy relations in greengram (Vigna radiata L.) under maize-based cropping systems. International Soil and Water Conservation Research, 3(4): 261-272.
Nunan N, Morgan M A and Herlihy M. 1998. Ultraviolet absorbance $(280 \mathrm{~nm})$ of compounds released from soil during chloroform fumigation as an estimate of the microbial biomass. Soil Biology and Biochemistry 30(12): 1599-1603.

Olesen, J.E., Berntsen, J., Hansen, E.M., Petersen, B.M. and Petersen, J., 2002. Crop nitrogen demand and canopy area expansion in winter wheat during vegetative growth. European Journal of Agronomy, 16(4): 279-294.

Radford P.J. 1967. Growth analysis formula their use and abuse. Crop Science, 7: 171175.

Rahman, M.Z., Islam, M.R., Islam, M.T. and Karim, M.A., 2014. Dry matter accumulation, leaf area index and yield responses of wheat under different levels of nitrogen. Bangladesh Journal of Agriculturist, 7(1): 27-32.

Sharma, S.K. and Sharma, S.N., 2004. Effect of cropping and nutrients applied to preceding crops on yield, nutrient uptake and economics of mungbean. Indian Journal of Pulses Research, 17(2): 138142.

Singh, Y., Singh, B. and Timsina, J. 2005. Crop residue management for nutrient cycling and improving soil productivity in ricebased cropping systems in the tropics. Advances in Agronomy 85: 269-407.

Timothy W, Joe E. 2003. Rice fertilization. Mississippi agricultural and forestry experiment station 13(48): 1-4.

Xu, Y., Nie, L., Buresh, R.J., Huang, J., Cui, K., $\mathrm{Xu}, \mathrm{B} .$, Gong, W. and Peng, S. 2010. Agronomic performance of late-season rice under different tillage, straw and nitrogen management. Field Crops Research 115: 79-84.

\section{How to cite this article:}

Swarna Ronanki and Behera, U.K. 2018. Effect of Tillage, Crop Residues and Nitrogen Management Practices on Growth Performance and Soil Microbial Parameters in Wheat. Int.J.Curr.Microbiol.App.Sci. 7(01): 845-858. doi: https://doi.org/10.20546/ijcmas.2018.701.103 